\title{
The Flight of The Accountant: a Romance of Air and
} Credit

\author{
by \\ Peter Armstrong \\ (BSc Aeronautical Engineering)
}

Contact Details

Professor Peter Armstrong

The Management Centre

University of Leicester

LE1 7RH

e-mail p.armstrong@le.ac.uk 
Abstract

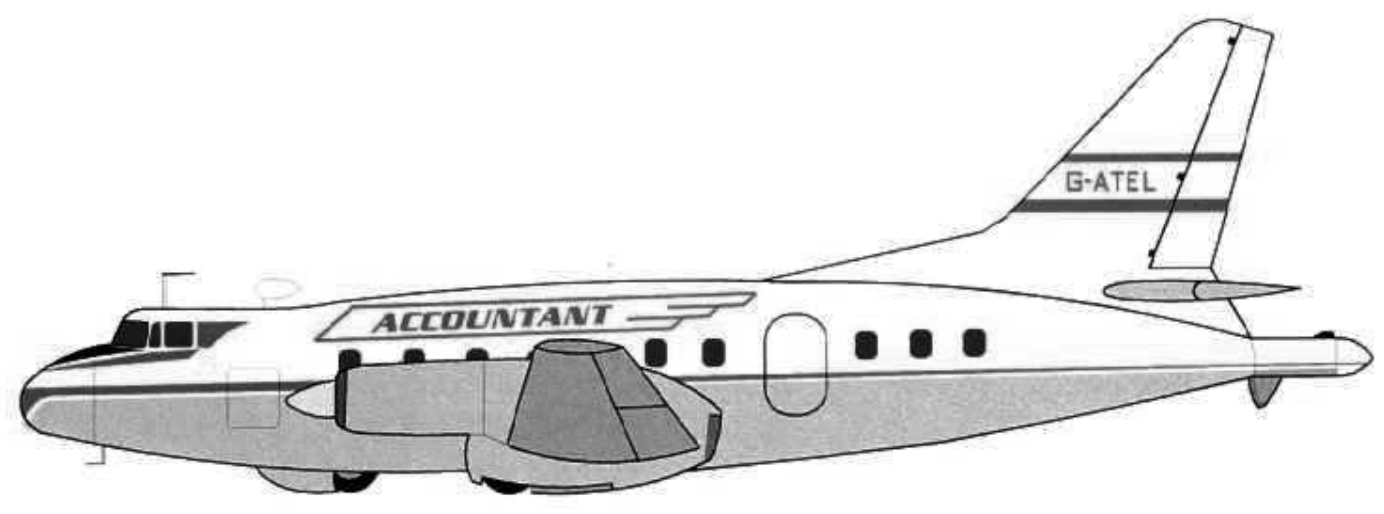




\section{Introduction}

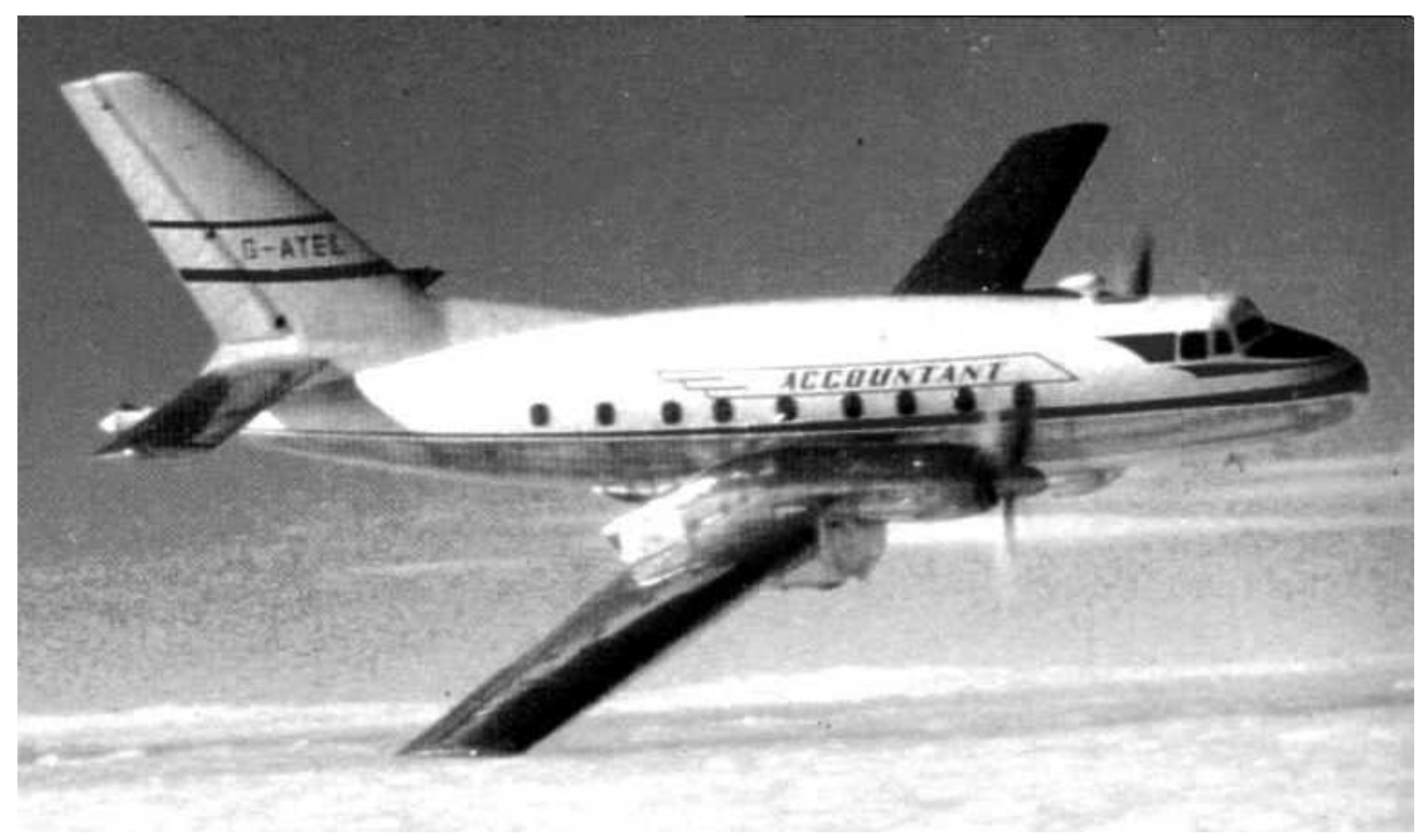

When the first flight of the Aviation Traders Accountant became imminent we were very pleased to be able to go along to Southend Airport and take part in the occasion, for such it certainly was with many of the company's workpeople out on the airfield to see their very first design take the air. Indeed a number of these found convenient extempore aeronautical grandstands on the dozens of exR.A.F. Prentices dotted about the airfield prior to their refurbishing as civil aeroplanes.

Although the weather was unsettled, the plans went ahead smoothly and after the chief test pilot, $\mathrm{Mr}$ L.P. Stuart-Smith and the chief of flight tests, Mr D. Turner B.Sc. (Hons), had climbed aboard, the two Rolls-Royce Darts were started up with a shrill whine and the square-tipped Rotol propellers bit the air purposefully.

The Accountant then taxied sedately to the end of the runway and turned into the wind, tension in the watching crowd mounting awhile. For several long moments the plump, silver partridge sat glistening and tranquil before the engines were opened up with a roar and the wheel brakes released.

Trundling along at first, the Accountant rapidly gained speed and soon lifted well clear, retracting its wheels almost as soon as it was properly airborne. Flying smoothly and steadily, it climbed away with the Darts in full song and in no time was a small shape in the distance. This was just before 3.45 p.m. on Tuesday, July 9, a time and date to be remembered by all at Aviation Traders (Engineering) Ltd.

After several wide circuits and a pass over the airfield, Mr Stuart-Smith lowered the double-slotted flaps fully and dropped the Accountant swiftly to the runway in a smoothly executed landing after about 25 minutes in the air.

No sooner had the prototype turned off the runway and parked than everyone was running wildly to the spot and gathered expectantly round the door. Hurrying from the control tower, Mr F.A. Laker, the driving force behind the whole undertaking was soon on the spot and boarded the aeroplane. Then, the door opened and to great applause the test pilot and flight observer emerged beaming with well-warranted satisfaction.

The Aeroplane July 19 1957. p. 78

The small figure scurrying across the tarmac in this remote scene is none other than the future Sir Freddie Laker. At this point in his career, he is an amply-proportioned 
young man of 35. He is the managing director of Aviation Traders, the company which built the Accountant, and of a small but growing airline, Air Charter. Skytrain, the no-frills economy airline aimed at the common man, with its fleet of fourteen wide-bodied jets is still 16 years in the future, as is Laker's iconic status as Mrs Margaret Thatcher's favourite capitalist.

\section{Trading in Aviation}

Laker's lifelong affair with aircraft began, so he says, whilst he was eating fish and chips with his friends at fourteen years of age. Looking up, he saw the great German airship Hindenberg and a four-engined Handley-Page 42 biplane airliner of Imperial Airways passing over Canterbury Cathedral at the same time . 'You couldn't think of two more dissimilar aerial objects than these two.' he recalled, many years later, 'A magnificent sight. And I said to my mates, I said, "that's for me. I'm going into aeroplanes.”' (NS archive, Laker 1)

Leaving school at 16, Laker began work at the Short Bros. Flying-Boat factory at Rochester. In 1941, he joined the Air Transport Auxiliary (ATA), becoming flight engineer to the ATA's chief test pilot, James 'Molotov' Watson. Watson later claimed that the young Laker was the only pupil he had taught to fly on four-engined aircraft. During his service with the ATA, Laker also learnt to patch and mend most of the World War 2 aircraft which were to become the bread-and-butter of Aviation Traders.

Demobilised, he became one of the first employees of British European Airways. 'But I only stayed three months, it was rather boring.' (NS archive, Laker 1) He then moved to London Aero and Motor Services (LAMS), a company whose business was the conversion of Halifax bombers for use as transport aircraft. The conversion was primitive, consisting of the removal of gun turrets and bombing equipment, the addition of a crude cargo-carrying pod under the fuselage and a change of name from Halifax to Halton. These aircraft were flown by an air charter company called Payloads which was associated with LAMS. Laker left LAMS in 1947 to set up Aviation Traders, but his company struggled for lack of capital and he also continued to fill in as Payloads' chief engineer. Realising that Payloads was close to bankruptcy (Eglin and Ritchie, 1980, p. 9, 12), Laker advised the owner, Bobby Sanderson, to sell out, and helped by finding a buyer for the company's Haltons. In return for this favour, so runs Eglin and Ritchie's account, Sanderson lent Laker £38,000 with which to buy twelve second-hand Haltons from the British Overseas Airways Corporation (BOAC). It was these aircraft, plus the spares which came with them, plus the opportunity to put both to profitable use, which set Aviation Traders on its feet.

Clearly there are pieces missing from this account. What could Laker see about the operation of Payloads that Sanderson could not? What was his motive for passing on the information and why was it worth over $£ 900,000$ in today's money?

Ironically for a devotee of free-market competition, Laker's opportunity to set his Haltons to work was presented by the Russian army of occupation in East Germany. In June 1948, they blockaded all traffic into West Berlin. The response of the Western allies was the Berlin Airlift, and it was decided, partly for propaganda reasons, that the main military effort would be supplemented by civilian carriers. For the many struggling airlines which had been set up after the war by ex RAF aircrew, the generous charter rates and the huge number of flying hours on offer were a lifeline. One of them was Bond Air Services, a company run by the brother of one of Laker's 
ATA friends. Initially Aviation Traders provided Bond with six aircraft and contracted to service them in return for half of the freight fees. At the peak of the airlift, Laker was maintaining Bond's aircraft, supplying spares and service for many of the other 90 or so planes involved in the airlift and flying the remaining six Haltons on his own account. He had nearly four hundred people working for him in the UK plus over thirty in Hamburg. As he put it later, 'Well, from my point of view there is no doubt about it that it made me into a relatively wealthy person. . . I was able to get enough capital together to stay in the business.' (NS Archive, Laker 3)

When the airlift ended in 1949 many of the airlines which had prospered from it promptly collapsed, Bond amongst them. A quick learner, in this respect at least, Laker turned his skilled engineers to the business of scrapping warplanes. Huge quantities of all types were on offer at prices as low as $£ 50$ each, at which price a profit could be made simply by reclaiming the metals from the airframes and engines. At one sale Laker bought no less than 99 Halifax bombers and six thousand RollsRoyce Merlin engines.

The success of this business seems to have encouraged Laker in the belief that there was always profit found in second-hand aircraft which no-one else wanted. In the early 1950s the most obviously unwanted aircraft was the four-engined Avro Tudor transport. The Tudor was a beast. On take-off, the massive torque from its four Merlin engines had to be counteracted by differential throttling of the port and starboard engines. Taxying, and consequently the early part of the take-off, was largely guesswork because the long nose and tail-down attitude obscured the forward view. Even from its days as a prototype, the Tudor had killed people. One of the worst accidents occurred in 1950 when one of two operated by the Fairflight charter company of Air Vice Marshall 'Pathfinder' Bennett, crashed on attempting to land at Llandow airport in South Wales. Seventy-five rugby supporters and five aircrew lost their lives in this accident and a few months later BOAC withdrew its three Tudors from passenger service. In 1951 the Minister of Civil Aviation decided there would be no more passenger-carrying certificates for the type (Merton-Jones, 1985). Big, fast and dangerous, the Tudor was a challenge to any red-blooded entrepreneur. And they were going cheap.

In the early 1950s, meanwhile, the War Office had discovered that it was cheaper, as well as quicker, to fly British troops to the remote trouble-spots of the empire instead of shipping them. It was the availability of these lucrative trooping contracts which drew Laker back into the business of flying. In 1951, he acquired Air Charter, a moribund company with useful tax losses and Fairflight, Bennet's company, whose principal assets were its surviving Tudor and a contract to carry freight between Berlin and Hamburg when the Russians blockaded Berlin once more in 1951. Having also acquired BOAC's three Tudors, Air Charter rapidly became the dominant airline on the 'little Berlin airlift', running 70 flights per week.

In the longer term, however, Laker's eye was on the trooping contracts, a task for which the Tudor, with its large capacity and long range seemed ideal, provided it could be modified so as to convince the civil servants it was safe. In 1953 he bought the entire stock of 13 aircraft held by the Ministry of Civil Aviation, a deal which included 88 new Rolls-Royce Merlin engines, the importance of which will appear later. Laker was now the owner of the world's entire stock of Tudor aircraft. They had been bought at prices rumoured to be in the region of $£ 10,000$ per aircraft, as against the new cost of around $£ 100,000$ (Merton-Jones, 1985). 
It remained to modify the aircraft so as to satisfy the Air Ministry and the War Office that they were safe for trooping. The man Laker recruited to carry out this work was Lionel 'Toby' Heal, a young designer frustrated at Hunting-Percival because a senior engineer, 'Johnny' Johnson, had blocked his attempts to introduce a new method of aircraft construction. As far as the Tudor was concerned, Heal's efforts were unsuccessful. Although the systems suspected of causing the Tudor accidents were either removed (pressurisation) or re-designed (hydraulics), the ministries remained unconvinced. After further modifications to improve cargo access, also by Heal, Laker's Tudors were mainly used as freighters, Two more fatal crashes in 1959, with the loss of fourteen lives ended Laker's adventure with the type. Despite the failure to adapt the aircraft for trooping, it was not an unprofitable one. The low initial costs of the aircraft were rapidly written off and Eglin and Ritchie estimate that the aircraft produced a cash flow of about $£ 1 \mathrm{~m}$ per year during their six years of service (1980, p. 41).

What finally cured Laker of the habit of buying up surplus aircraft at knock-down prices was his 1956 acquisition of the RAF's entire stock of 252 Hunting-Percival Prentice trainers. The intention was to refurbish them for the civilian light aircraft market. Littered around Southampton airport, these were the 'extempore aeronautical grandstands' from which the workers of Aviation Traders were later to witness the first flight of the Accountant. Stable, but over-sized, clumsy and thirsty, the Prentice was caught out by the relaxation of import controls on light aircraft. Even at Aviation Traders' bargain prices, they were no match for the sophisticated and economical Cessna and Piper types which were becoming available from the USA. Only 20 or so Prentices were sold. The rest quietly mouldered until they were broken up for scrap.

Laker's eventual entry into the trooping business came about through another fatal accident and the aircraft involved were Avro Yorks, not Tudors. When a Skyways York carrying the wives and children of servicemen was lost over the Caribbean, safety inspections assumed a much greater role in the award of contracts, bringing to an end the ministry's practice of favouring the lowest tender regardless. Basically the wing and tail of a Merlin-engined Lancaster bomber carrying a slabsided fuselage, the York was an aircraft which Aviation Traders had been breaking and building for years. As a result, the company's Yorks were converted and maintained to higher standards than those of its competitors. Through buying-up war surplus, moreover, Aviation Traders possessed vast stocks of Lancaster and Merlin spares which could be placed along the charter routes in case of breakdowns. Under the new inspection regime, Air Charter quickly obtained their trooping contracts and by February 1953 the fleet had expanded to include seven Yorks, four Tudors, a Dakota and a Bristol 170 Freighter. Later in the year, thirteen more Tudors were added, as already recounted.

In the course of renovating and modifying these and other aircraft, Aviation Traders was developing a manufacturing capability, and in 1951 the company won a contract for making the wing centre sections for Bristol's inelegant but capacious 170 Freighter. In part the unimpressive aerodynamics and lumbering performance of this aircraft were due to the large bulbous nose which hinged at either side to allow for the loading and unloading of bulky cargo. As long ago as 1948, Silver City Airways had spotted the potential of this feature and was using the Freighter as a cross-channel car ferry. Laker went into competition. In 1953, he set up Channel Air Bridge as a subsidiary of Air Charter and was soon flying four Freighters between Southend and Calais. 
Meanwhile, the Accountant was taking shape.

\section{The Flight of the Accountant}

When we last encountered Toby Heal, he was designing the pressurisation system out of the Avro Tudor, re-routing its suspect hydraulics and enlarging the doors so they could be operated as freighters. In poaching this ingenious young designer from Hunting Percival, however, Laker was taking in something of an obsession.

In 1954, Heal had taken out a patent on what he called the 'tensioned skin' system of construction. In earlier wood-and-fabric aircraft, much of the stiffness of the airframe was provided by the fabric covering which was tightened by doping. Heal's idea was to achieve the same effect with a metal skin. The patent describes a dual-curved fuselage assembled from frames which were temporarily pulled flat during the attachment of the outer skin. When the frames were released, they would spring back into their natural curvature thereby pulling the metal skin into tension, both round the fuselage and along its length. Because of the skin's contribution to the strength of the structure, it could then be considerably lightened, so increasing the aircraft's payload. Hence the name Accountant.

For the method to work as envisaged in Heal's 1954 patent, the aircraft's fuselage had to be designed so that its outer skin curved in two directions at once, both round its circumference and along its length - of which more in a moment. In a later patent of 1956 - too late to influence the design of the Accountant - Heal extended his concept to singly-curved and even flat panels. Flat frames, for example, could be pulled into a dual curvature and the skin attached to the concave side so that it would be tensioned when the frames were released.

Laker was enthralled by Heal's ideas. The young designer was installed in a small office at Aviation Traders and given the go-ahead to recruit a team to design an aircraft around his tension skin system. As originally conceived, the ATL 90 Accountant was going to be a short-range transport seating around thirty passengers. In other words, it was to be a DC3 replacement.

For the aircraft designers of the 1950s, and for some years thereafter, the question of how to break the stranglehold of Douglas' DC3 on the market for short-range passenger aircraft was the equivalent of the alchemists' search for transmutation. One of the greatest achievements of $20^{\text {th }}$ century design, the DC3 first flew in 1935. At a time when most of the world's frontline fighter aircraft were $150 \mathrm{mph}$ biplanes, it was a streamlined twin-engined monoplane capable of carrying up to 35 passengers for ranges up to 1500 miles at cruising speeds of just under $200 \mathrm{mph}$. In service, the type proved to be tough, reliable, adaptable and endlessly patchable. By the end of the Second World War, well over 20,000 had been built. They were in service all over the world, and so were the spares and the competence to install them. Above all, as war surplus, they were cheap. The problem for the designers and manufacturers of the Post World War 2 era was that a credible replacement would have to show major advantages over the DC3 to justify the extra cost, for example in comfort, economy or speed.

In the increased payload promised by the Accountant's tension skin construction, Heal and Laker believed they had part of the answer. The other part lay in the Rolls-Royce Dart turboprop. For all its virtues, the DC3 was a piston-engined aircraft, noisy and, by modern standards, a boneshaker. The turboprop by contrast has only rotating parts; 
nothing reciprocates. To achieve advantages in comfort over the DC3, Laker's Accountant needed turboprops, and the obvious choice was the Rolls-Royce Dart. By 1953, the Dart was already a proven design, having seen over two years' domestic service with the highly successful four-engined Vickers Viscount. Darts, however, were in demand, partly because of the success of the Viscount. The story of how Laker obtained two for his prototype tells us much about the man - and something about the tactful approach of his biographers.

As the holder of the largest UK stock of new and used Merlin engines and spares, Laker had been useful to Rolls-Royce over the years as a supplier of both. Because it would have damaged the Rolls-Royce image to be seen buying second-hand, the relationship was discrete, taking the form of exchanges in kind. Laker was fond of boasting that he had never paid for an engine overhaul at Rolls. In consequence, he felt confident enough to ask Lord Hives, the company's chairman, for the free and indefinite loan of two Dart engines. Knowing nothing of his company's clandestine dealings, Hives 'let it be known that Laker would find it easier to get the shirt off his back' and, at a later meeting, pointed out that Laker already owed tens of thousands of pounds for unpaid service work. According to Eglin and Ritchie, Laker's reply was, "I didn't think you were worried about sums like that. I never usually bother. As a matter of fact you owe me considerably more.” (1980, p. 50). The two Darts, our biographers tell us, were on the next train to Southend.

Is it fanciful to imagine that there might have been more to the exchange than Eglin and Ritchie tell us - or than Laker told them? At all events, he had his two Darts.

The next step was to build his prototype. Needing a project manager, Laker once again raided the design offices of Hunting-Percival, this time coming back with none other than 'Johnny' Johnson, the man who had originally turned down Heal's tension skin project. Johnson, apparently, took up his new post before discovering that the aircraft he was to build was designed around a method of construction which he distrusted. Was Laker aware of the friction between Johnson and Heal? The evidence suggests that he fully expected Johnson to build the Accountant around Heal's tension skin fuselage, since he did his bit to promote the design by denigrating the 'aloominium toobs' of conventional aircraft to all who would listen (i.e. cylindrical fuselages whose skins curve in only one direction for most of their length).

In all likelihood, the technology was doomed from the moment Johnson was recruited. Laker's wrecking crews had seen a lot of battered aircraft and they, like Johnson, were worried that the highly loaded skin and light supports of Heal's system would fail catastrophically if anything punched a hole in it. The tension skin concept was dropped in favour of an unstressed skin conventionally riveted to the aircraft's bulkheads and stringers. Heal seems to have walked off the project in disgust. In the 1956 edition of Jane's All the World's Aircraft, the name of the Accountant's chief designer was given as Heal (p. 49). In the 1957 edition it was A.C. Leftley (p. 54). By then, however, the Accountant, had been decisively shaped by Heal's tension skin system, thus ensuring that the aircraft had all the disadvantages of the system and none of the advantages.

In order to maintain the dual curvature of the skin called for in Heal's 1954 patent, the fuselage was shaped like an elongated tear-drop. Excellent as an aerodynamic form, the taper towards the nose and tail severely limited the passenger-carrying capacity of these sections of the fuselage. Of lesser importance, though still significant, the sharp taper at the rear shortened the fuselage so that a large, swept-back fin was required to 
ensure directional stability (The Aeroplane July 12 1957). Thus the economy promised by the core feature of the Accountant, even if it had been realised, would have been compromised by the loss of interior space and the extra weight and drag of the fin. The portly fuselage of 'the plump, silver partridge' moreover, together with the 'rather ugly hump' behind the cockpit occasioned by the teardrop profile of the fuselage also contributed to what a Flight journalist described as 'a certain ungainliness from some angles (more particularly upon the ground)' Although unlikely to have been decisive, this may have contributed to the aircraft's ultimate lack of appeal (Flight Vol. 73. 31 Jan 1958 p. 131).

On the day appointed for its maiden flight, unfortunately, the Accountant disgraced itself. Laker had assembled the press, photographers and various aeronautical notables to witness the event. In the rush to get the plane into the air, the flight itself was to be preceded by a test of the automatic fire extinguishers which were designed to release foam into the engines when activated by crash-pads on the underside of the wings and fuselage. In order to test the electrical circuits, the extinguishers had been isolated by removing the fuses and replaced by a bell circuit. The idea was that the bell would ring when the crash pads were struck, thus proving the integrity of the system. Unfortunately a safety-conscious mechanic was under the impression that the test had already taken place. Quite properly, given his view of the situation, he removed the bell and re-installed the extinguisher fuses so that when the crash pads were struck, both engines were flooded with foam in an aeronautical equivalent of the human orgasm. Extinguisher oozing from every orifice, the Accountant stood immobilised for a week (Eglin and Ritchie, 1980, p. 52). Laker, as was his tendency, fired everyone within earshot - except that he also expected them to report back for work when he had cooled down - except, that is, for the ones he intended to stay fired.

In many respects, the Accountant was forward-looking, if not actually innovative. The aluminium skin was flush-riveted (as against the goose-pimple aesthetic of the DC3); the structure featured multiple load-paths to prevent the propagation of fatigue cracks and the entire fuel supply was carried outboard of the engines for safety. Not surprisingly, given the background of Aviation Traders, the aircraft was designed with the maintenance crew in mind. The Aeroplane's 'Ventral View' of the Accountant shows easily accessible servicing hatches underneath the forward fuselage and inboard wing leading-edges. (The Aeroplane July 12 1957, p. 50)

More visible was the unusual design of the engine nacelles. A turboprop produces jet thrust as well as the traction of the propeller and this is most efficiently used if the exhaust path is straight. The Accountant achieved this by mounting the engines above the wing, so that the airflow through them did not have to be routed clear of the wing spars. This arrangement also lifted the propellers high above the ground, so that the undercarriage could be shortened (and therefore lightened). The downside was that this too probably looked ungainly to those accustomed to the aesthetics of the piston engined transport. To an unsympathetic eye, the engines nacelles could look like stunted forearms reaching forward for some means of levering the ample belly of the Accountant into a flying attitude.

In flight, the visual impression of too much weight south of the equator proved to be very much an illusion. Contrary to The Aeroplane's report of a trouble-free first flight, the centre of gravity turned out to be too far forward, so much so that full up-elevator was insufficient to hold up the nose at landing speeds. As a result it was only possible for the pilot to land the Accountant by despatching the observer to add his weight to 
the extreme rear end. In the light of this, the aplomb with which the two emerged from the test flight appears even more praiseworthy than reported by The Aeroplane.

Laker's sales pitch for the Accountant varied according to his audience. Although its original specification was that of a 28 seat DC3 replacement cruising at 256 knots over a range of 1000 miles, he soon began to hedge his bets by also promoting it as a long-range executive transport capable of covering stage lengths of nearly 2,500 miles with two three-seat settees and eight passenger seats (The Aeroplane, $12^{\text {th }}$ July 1957 , p. 48; Air Pictorial, Vol. 19 No. 9 Sept 1957. p. 291. A later passenger version, the ATL91, was projected, with a (cylindrically) stretched fuselage carrying forty passengers.

Manufacturing was problematic as well as markets. Although over 1000 people were employed at the height of the development work, the resources of Aviation Traders still fell far short of what would have been required to manufacture the Accountant in quantity. Laker's hope was that he could interest buyers in placing orders for the aircraft and established manufacturers in producing it under licence. Given the painful contractions faced by the British aircraft industry in the mid 1950s, it is perhaps understandable that the expressions of interest from various companies in the USA and UK were reported in the aviation press with a very positive spin. An exception were the Delphic mutterings of 'Roving Spotter,' 'One of the big question marks in British aviation affairs at this time is the Aviation Traders Accountant. As I do not wish to be controversial, I shall express no opinion ...' (Air Pictorial, 1957, Vol. 19, p. 193)

In The Aeroplane's report of the Society of British Air Constructors' show of 1957, the unease is spelt out; 'The problem, so far as Aviation Traders is concerned, is to convince prospective customers that the aircraft can be built, for the company is a complete newcomer to aircraft production and many operators - business or airline might feel this is a disadvantage in placing an order with the company.' The report goes on to mention Lear in the USA and Gloster Aircraft and Hunting Percival in the UK as possible licensees (The Aeroplane, $6^{\text {th }}$ September, 1957 p. 374). Hunting Percival, however, was busy promoting its own idea of the executive transport at the same show. A much smaller aircraft than the Accountant, the President was a six-seat version of the RAF's twin piston engined Pembroke staff transport and reconnaissance aircraft. Gloster Aviation, on the other hand, expressed some interest in producing the Accountant, not least because production of their Javelin deltawinged fighter for the RAF was running down. Unfortunately for Laker, the company had recently been taken into the Hawker-Siddeley Group as part of the government's rationalisation of the UK aircraft industry, and it was not represented on the main board. Gloster's proposal to manufacture the Accountant was turned down, almost certainly because Avro, also part of the Hawker Siddeley Group, was by then committed to the Avro 748, an aircraft in the same class.

Still flying as the workhorse of UK domestic aviation under the inflated pseudonym of ATP ('Advanced Turboprop'), the 748 first flew in 1960, as against to the 1958 of its major UK competitor, Handley-Page’s Dart-Herald (1955 for the original Herald with four small piston engines) and 1957 for the Accountant. In one of its design features, the raised thrust-line of its engine nacelles, the Avro 748 bore a striking resemblance to the earlier Accountant, so much so that Laker contemplated suing Hawker-Siddeley. Always thereafter he insisted on referring to the aircraft as 'The Avro Accountant' and never dealt with Hawker again (Eglin and Ritchie, 1980, p. 53) 
The 748, in the opinion of some, was the beneficiary of the politics of industrial rationalisation rather than its own merits as a design. In competition with the Herald, in particular, the 748 benefited from the refusal of Sir Frederick Handley-Page to join one of the government-sponsored aircraft consortia, as a result of which his company was starved of government business (Banks, 1982, p. 31). The 748, in contrast was ordered for the RAF as the Andover, a move which probably also enabled the aircraft to survive competition with the Dutch Fokker F27 Friendship.

The F27 ultimately proved to be the nearest thing to a truly successful DC3 replacement. First flying in 1955 (with Rolls-Royce Darts), the Friendship sold 581 units built by Fokker, plus 205 built under licence in the USA by Fairchild. Total sales of the Avro 748 (subsequently HS 748, and BAe 748) were 382 up to 1988 when production ceased. Only 50 Heralds were ever produced - and only one Accountant.

The 1957 SBAC show turned out to be the Accountant's swansong. Flight magazine of $31^{\text {st }}$ January 1958 carried the following report:

\section{Au revoir Accountant}

On January 10, the Aviation Traders (Engineering) Accountant took off on what may have been its last flight - at least for some considerable time. On that day, after some 50 hours flying since the first flight on July 9 1957, this brave project virtually came to an end. The Accountant has been mothballed at Southend, Aviation Traders having given up a valiant struggle to find a manufacturer to take over the project and bring it to fruition. The company have not the resources to continue the work alone; and with no hope of Government backing if things went wrong, there were no industry takers. Aviation Traders had asked only to cover their development costs (plus, they hoped, a small profit) after 200 or 300 production aircraft had been sold.

Many will say "I told you so" about the failure to obtain industry backing; the difficulties of a small company competing in the DC3 replacement market; and the impossibility of selling an aircraft with no delivery date. Yet others will sorrow that the enterprise has not succeeded, for the Accountant was well timed and attracted a great deal of airline and executive interest. Rolls-Royce provided the Dart, and the airframe showed promise of exceptional life.

Flight. Vol. 73. $31^{\text {st }}$ Jan 1958 p. 131

The two Dart engines were taken out and shipped back to Rolls-Royce. Most of the workforce who had cheered the first flight less than a year earlier were laid off. An aeronautical memento mori, 'The gutted ghost of the Accountant stood forlornly on the edge of Southampton airport for four years before it was finally dismantled for scrap' (Eglin and Ritchie, 1980, p. 54). Laker had spent $£ 650,000$ in developing the aircraft and shortly afterwards, he sold out both his companies, Aviation Traders and Air Charter, to Airwork. Under government pressure, Airwork, merged with Hunting Clan in 1960 to form British United Airways, with Laker emerging from the scrimmage as managing director.

Aviation Traders, meanwhile, retained its identity long enough to make a final foray into aircraft conversion. The Bristol Freighters flown by Channel Air Bridge were running out of steam. The repeated landings necessitated by the short ferry flights were causing metal fatigue in the wing spars and British cars had grown too big for the aircraft (by an average of 10 inches between 1950 and 1959). Eglin and Ritchie present us with a picture of Laker leaping from his bathtub one evening, like Archimedes before him, with the solution fully formed in his mind (1980, p. 77). It was a 'chop' of the Douglas DC4. Like the DC3 before it, the four-engined DC4 had been produced in huge quantities and heavily-used examples were available for as little as $£ 50,000$. Laker's plan was to re-locate the cockpit above the fuselage, raise the load platform inside the aircraft in order to make it wide enough for cars and hinge 
the nose at one side, in order to allow them to be loaded and unloaded from the front. These modifications called for a re-routing of the controls and an enlargement of the tailfin. In this form, the ATL98 Carvair (Car-via-air) would take five cars and 23 passengers. In all, 21 of these strange-looking aircraft were built between 1961 and 1968. No longer used as car ferries, but still useful for carrying awkward and bulky objects, three of them are still flying (Carvair)

\section{Flight to Insolvency}

Laker had done with the Accountant, but accountancy had not done with Laker.

Following a dispute with the chairman of British United Airways, Sir Miles Wyatt, over the dismissal of an employee, Laker left the company late in 1965. Still independently wealthy from the sale of his companies eight years earlier, he set up Laker Airways in Jersey so as to avoid UK taxes and the then-current labour legislation through which his employees might have been able to obtain the same wages and conditions as the state-owned carriers. Low wages were a habit with Laker, and they were essential to his future plans. At the same time, he set up Laker Leasing as a UK company in order to obtain the licence needed to run a UK-based airline.

With the lease of two Boeing 707s from the receiver of the bankrupt British Eagle company, Laker first entered the Atlantic market in 1969, as a charter operator. At this time, the International Air Transport Association (IATA) allowed low fare charter flights only for pre-existing groups of passengers who could establish 'sufficient affinity.' This was interpreted to mean membership of at least six months' standing in a group of less than 20,000 people defined so as to set it clearly apart from the general public. Since transatlantic charter fares were typically about $£ 80$ return, as against $£ 240$ for a scheduled flight, imaginative readings of the affinity rules were typical of all charter operators. Laker, however, seemed to be caught out more often than most. In 1971, Independent Television News broadcast the affecting sight of weeping grandmothers who had been travelling as members of 'The Left-Hand Club' being herded gently out of one of Laker's 707s (Eglin and Ritchie, 1980, p. 139-40). Incidents of this kind gave Laker the reputation of a shady operator with the US authorities. Later this image was to work both for and against him.

In 1973, Laker was granted a 10 year licence for Skytrain by the British Civil Aviation Authority (CAA), who accepted his argument 'that there is a substantial demand for cheap, no-frills, short-notice, mass travel which is not presently adequately catered for.' (Banks, 1982, p. 39). Under the reciprocity provisions of the Bermuda Treaty which regulated air traffic between the UK and the USA, American approval of a carrier designated by the British government, should have been automatic. Instead the American Civil Aeronautics Board (CAB) objected, citing Laker's breaches of the charter affinity rules, though the real motive was probably to protect the US airlines North Atlantic and Pan-Am, both of which were losing money at the time. Unfortunately for Laker, the delay ran into the OPEC oil crisis of 1974. In that year, oil prices quadrupled and air traffic across the Atlantic declined by $8.5 \%$. Meanwhile capacity had actually increased due to the airlines' herdlike rush into Boeing 747s and other wide-bodied jets. In September, there were talks between Trans World Airways (TWA), Pan American World Airways (Pan-Am), the stateowned British Airways (BA) and the independent British Caledonian (BCal). The talks were held at the CAB's offices, with observers from the CAA in attendance. The Americans made it clear that any agreement on an orderly reduction in capacity was 
conditional on the continued exclusion of Skytrain. Learning of this deal during a television interview, Laker exploded at the 'bums and gangsters' of the British civil service who had connived at the American demands. Through his American Lawyer, Bob Beckman, he filed suit against the airlines, claiming damages of $£ 7 \mathrm{~m}(£ 17,000 \mathrm{a}$ day for five months) for the delays to Skytrain. It turned out to be a dry run for the future.

Meanwhile there were changes in UK civil aviation policy which seemed at first to threaten even Laker's existing position. Peter Shore, Secretary of State for Aviation in the incoming 1974 Labour Government, produced a White Paper which set out a plan to carve up Britain's overseas airlanes between BA and BCal. BCal's sphere of influence was to be South America, West and Central Africa and the Southern USA whilst BA was to be the sole carrier between the UK and the Northern USA, including New York. Laker's Skytrain had no place in this rationalised vision of the future, and his license was to be revoked. Unfortunately for Shore, his plan was derailed by the House of Lords. Whilst the spheres of influence marked out for the major UK carriers were agreed by their Lordships, the plan to revoke Laker's licence was thrown out, and the government's attempts to persist with it were rejected in a succession of appeal court judgements. Meanwhile Shore's successor at Aviation, Edmund Dell, had become concerned that the balance of revenues between American and UK carriers on the North Atlantic route had drifted out to more than 2:1 in the Americans' favour. Dell's strategy for rectifying this imbalance was to demand 'single designation' in a renegotiation of the Bermuda Treaty, meaning that only one airline from each country would be allowed to fly on each route. Already a fait accompli on the UK side, as a result of confining the two major carriers to their respective spheres of influence, single designation was impossible for the Americans to accept, since it would have meant either Pan Am or TWA giving up New York - London. At this point, Lakers' licence for Skytrain, and his murky image with the Americans, suddenly appeared to the British as a negotiating asset. If the Americans were going to insist on double designation on the London routes, the British would threaten to nominate Skytrain, indeed could only nominate Skytrain, as the second British carrier. If it was intended as a bluff, it didn't work. Double destination was too important to the Americans to be abandoned, even at the cost of admitting the morally suspect Laker to US airspace. Suddenly, after six years of trying, Laker had his US permit. The first Skytrain flew from Gatwick to New York on $26^{\text {th }}$ September 1977 with a full load of passengers. They had paid only \$102 one-way or \$236 for the round-trip, as compared with $\$ 626$ for a normal economy ticket from the established carriers (Hellary, 2001).

Well before this flight took off, Laker had been buying aircraft, and buying with his usual eye for a bargain. In the early 1970s, the world's airlines were offered a choice of two three-engined, wide-bodied airliners, the McDonnell-Douglas DC10 and Lockheed's Tristar. To the casual observer, the major difference between these aircraft is that the central engine of the Lockheed is situated in the rear of the fuselage, whereas that of the Douglas is mounted in the fin. It was the inner difference which was the more important: the Tristar used British-made Roll-Royce RB211 turbofans against the American General Electrics of the DC10. Crucially the development of the RB211 had been delayed by its pioneering use of carbon composites, a delay which brought about the demise of Rolls-Royce Engines as it had hitherto been known, and its re-emergence as Rolls-Royce (1971). Around the campfires of accountants, the story of the Rolls-Royce collapse is still told to this day, illustrating as it does the 
perils of allowing engineers to make any decision whatsoever, without the approval of accountants. Of this fundamental error, the Tristar was a casualty, and a very large one. It meant that in any competition with McDonnell-Douglas, Lockheed were always coming from behind. A case in point was the All-Nippon contract.

Having obtained a favourable deal from McDonnell-Douglas, Japan's domestic airline, All-Nippon, had placed an order for six short-range DC10's through its parent company, Mitsui Trading. Desperate to sell the delayed Tristar, Lockheed bribed various Japanese officials and politicians into threatening All-Nippon with the loss of its licence unless it cancelled the DC10s in favour of Tristar. All-Nippon caved in and bought the Tristar, but Mitsui found itself unable to cancel the order with McDonnellDouglas because the Japanese government of the day was highly sensitive to the issue of trade imbalances with the West. As a result, Mitsui had become the owner of six unwanted DC10s at a cost of nearly $\$ 150 \mathrm{~m}$. In 1971, the company managed to unload three of them onto Turkish Airlines, one of which later crashed in Paris with the loss of 346 lives. Enter Laker, who had calculated that the substitution of fuel tanks for some of the cargo space and careful operating procedures would enable even the short-range variant of the DC10 to cross the Atlantic. Anticipating that American approval for Skytrain would quickly follow from his UK licence, he bought his first two DC10s from Mitsui in 1972 and the third in 1974. The terms were favourable indeed. He claimed the $10 \%$ commission on the sale for his airline and used it as a down payment. The rest of the purchase price was to be repaid at $6 \%$ over ten years. As the negotiations were drawing to a close, Laker sounded out a number of travel agents on the prospects of filling an aircraft as large as the DC10 (up to 380 seats on short runs, as against the Boeing 707's 180). Finding that the agents were distinctly worried, he insisted on inserting a clause in the contract which meant that he would only be paying for the planes as flying revenues were earned.

Still a year before the inaugural flight of Skytrain, he purchased a fourth DC10 direct from McDonnell-Douglas. This was actually the second prototype and the knockdown price reflected the considerable wear-and-tear of McDonnell-Douglas' flight test and certification programme. Finance for this aircraft was arranged through the Clydesdale bank.

Early in 1979, Laker ordered two more short-range DC10s from Mitsui. This time the Japanese conglomerate had bought the aircraft under the 'Samurai Loan' programme. Still exercised by Japan's trade imbalance with the West, the government advanced these loans to Japanese corporations so that they could buy Western manufactures which they were then free to lease or sell to anyone who could find a use for them. This time Laker obtained his two DC10s for $\$ 59 \mathrm{~m}$, repayable at $8.25 \%$ interest over 20 years, again with no down payment.

Later in the same year he contracted to buy five more DC10s direct from McDonnellDouglas, the long-range version this time. This purchase was financed by loans totalling $\$ 228.3 \mathrm{~m}$ at rates varying from $6 \%$ to $9 \%$ over nine years. $\$ 86.8 \mathrm{~m}$ of the money was advanced by the Export-Import Bank (Exim) an agency of the US government whose mission is to assist American exports by lending money to people who might want to buy them. Exim also guaranteed $\$ 74.5 \mathrm{~m}$ raised by the Private Export Funding Corporation, an organization which exists to raise private finance for government-approved export deals. Most of the risk of lending money to Laker Airways was therefore borne by the US taxpayer. As the manufacturer of the airframes, McDonnell-Douglas advanced \$14m whilst General Electric, who supplied 
the engines, supplied $\$ 7 \mathrm{~m}$. The remaining $\$ 46 \mathrm{~m}$ was raised by a consortium of banks. As is customary in the world of aircraft finance, the two manufacturers, also agreed to cover $25 \%$ of any loss on Laker's first sale of the aircraft (the so-called 'first-loss guarantee'.)

In September 1978, Laker ordered ten Airbus A300-B4s, another wide-bodied jet capable of carrying over three hundred passengers. This time, he was able to take advantage of the complex politics of directing employment in the European Community through the purchases of airlines and the assignments of work in collaborative manufacture. As these stood in the late 1970s, British Aerospace (BAe) manufactured the wings of the Airbus, but did so as a contractor to Airbus Industrie, rather than as a full member of the consortium because some years earlier the UK government had refused to fund the required injection of capital. The euro-politics of the Labour government of the day now dictated that BAe should buy back into the consortium, and part of the French price was that British Airways should order the A300, sales of which had been slow to pick up. BA, however, wanted the rival Boeing 757, a preference which presented the UK government with a dilemma. Boeing, unlike Airbus, offered the engine option of British-built Rolls-Royce RB211 turbofans, and work at Derby on the RB211 would safeguard more UK jobs than BAe's Airbus wings at Chester. An order from Laker offered a potential way out of this no-win situation - provided the French could be persuaded to accept it as a substitute for an order from BA. Knowing that both Airbus and the British government were anxious for the deal to go ahead, Laker played his hand for all it was worth. Although he agreed the normal base price of $\$ 42 \mathrm{~m}$ each for his first three Airbuses, the price was stretched to include training for three crews per aircraft, instead of the normal $1 \frac{1}{2}$, and it also included letters of credit from Airbus for spare parts and ground equipment from outside vendors. All told, these concessions were worth $£ 7 \mathrm{~m}$, an amount roughly equal to the down-payment. Once again Laker's purchase was effectively cash-free. The workers of Rolls-Royce Derby knuckled down to the manufacture of RB211s, BA flew them in their Boeing 757s, and BAe duly re-entered the Airbus consortium.

'Under discrete pressure from the British Government' (Banks, 1982, p. 101), the purchase of these three aircraft was financed to the tune of $\$ 131 \mathrm{~m}$ by a consortium of thirteen banks, led by the Midland. Though the loan was at market rates as far as the consortium was concerned, the UK government, by now that of Margaret Thatcher, did its bit by subsidising Laker's interest payments down to a constant $10.2 \%$, stoutly denying the while that public money was involved. Since the Bank of England Base Rate was then $16 \%$, the annual amount not involved would be about $\$ 10.5 \mathrm{~m}$.

The Midland's corporate director of finance expressed his misgivings. 'Sir Freddie Laker . . now has ten or eleven DC10s, all of which he has purchased in the last three or four years. Now he has purchased three A300s. The amount of money involved there is vast. His capital resources are not vast.' Indeed they were not. Laker Airways' 1980 balance sheet showed long-term debt and hire purchase balances of $£ 111.4 \mathrm{~m}$ against only $£ 504,000$ of fully paid-up share capital, though the Chairman's report contained a proposal to increase this by capitalising $£ 4.5 \mathrm{~m}$ of reserves.

By 1981, therefore, Laker had purchased, almost entirely on credit, and at interest rates variously subsidised by manufacturers and governments, a total of fourteen wide-bodied jets, each capable of carrying well over three hundred passengers. How had his ability to make money from these aircraft progressed during the same period? 
Following Skytrain's 1977 inaugural flight from London to New York, Laker obtained a licence for London-Los Angeles in 1978. Business on this route was slow to pick up at first, partly because the short-range DC10s which he was using at the time, could only make the trip by stopping off at Bangor, Maine, and partly because the lure of Laker's cheap fares was offset in the Californian mind by the prospect of travelling with unwashed students who also found the fares attractive. For much of 1978, Laker's average load factor on this route (seats occupied as a percentage of seats offered) was only 32\%, more than wiping out the profits made on the New York flights. Adding to these woes, an American Airlines DC10 crashed in May 1979, killing all 274 people on board, with the result that the aircraft was grounded worldwide for 6 weeks. Laker had no choice but to suspend Skytrain, reducing group profits for the year to March 1980 to $£ 236,080$ on turnover of $£ 111.4 m$ as compared with the 1979 figures of $£ 2.5 \mathrm{~m}$ on revenues of $£ 91.7 \mathrm{~m}$.

By 1981, however, Laker's new long-range DC10s were able to make the Los Angeles trip non-stop and his share of the traffic on this route, like that on London New York, was broadly in line with the capacity offered. Although this was an improvement, the stabilisation of Skytrain's load factors at levels similar to those of the established airlines was disappointing. The low fares should have translated into higher load factors than his competitors, not parity. Probably they would have done so if the established airlines had not responded with low fare packages of their own.

Even before Skytrain got off the ground, BA had introduced Super-Apex, a cheap advance-booking fare. TWA's solution was standby flights, whilst Pan-Am produced a mixture of the two (advance booking, but with the airline deciding the actual date of travel) (Banks, 1982, p. 141). The fares for all three were only slightly above Skytrain's, prompting accusations from Laker of collusion and predatory pricing. Laker Airways, he claimed, could make profits at Skytrain fares whereas the established airlines could not.

There was, of course, something in this. As well as paying lower salaries, a cut-price operator like Laker always has the advantage of skimming the bottom end of the market, effectively transferring the costs of sales and promotion onto the bargain hunters themselves. In Skytrain's first year of operation, these costs were only $4.7 \%$ of total operating expenses, compared to an average of $15 \%$ for IATA members (ibid, p. 75). Although such a fervent advocate of free markets could scarcely have expected his competitors to do nothing. the conviction had lodged in Laker's mind that Skytrain was the victim of a conspiracy by the international air transport oligopoly to drive it out of business.

In Banks’ opinion, however, Laker Airways’ main problem was not competition from the established carriers on prime routes, but the impossibility of opening up enough new routes to fill the fat fuselages of its rapidly growing fleet of DC10s and A300s (1982, p. 127-134)

By 1979, the airline had obtained licences from London, Manchester and Prestwick in the UK to Los Angeles, Honolulu, Tokyo and Sharja (United Arab Emirates). If he could add London - Hong-Kong, Laker reasoned, he could link up these routes so as to offer services to most of the world's major destinations without abandoning his passengers to whatever fares other airlines might charge them to complete their journeys. Hong-Kong, however, was a Crown colony at the time, subject to the unilateral decision of the CAA and with no provision for appeal. Laker's application was turned down on the grounds that there was no reservoir of charter passengers on 
this route from which the clientele for a walk-on service might be drawn. Similarly, he was kept out of Australia, by a government determined to maintain the BAQuantas duopoly on the UK-Australia route.

There remained Europe. In purchasing the Airbus, Laker had it in mind to fly scheduled services within the EC, which was then (and is now) organised through the IATA so that the routes between any two countries are divided between the national carriers of those countries, with the revenues equalised irrespective of the number of passengers actually carried. Laker attempted to challenge the exclusion of thirdcountry carriers by applying for no less than 630 routes connecting 37 major destinations within the EC. Despite his attempt to get a high court ruling that the Treaty of Rome implies free competition in air transport, the application was vetoed. The only European route Laker ever obtained was London-Zurich, and Switzerland, of course, is not a member of the EC.

The remaining possibility was a return to the holiday market, and here he spotted an opportunity in Florida, a part of the world which is abandoned by discerning Americans during the sticky heat of high summer, leaving the hotels half-empty. Great Britain, however, is a nation ravaged by seasonal affective disorder and its natives have proved themselves willing to suffer almost any discomfort for the strike of sun on their vulnerable white flesh, the more so if this can be achieved by the swimming-pool of a cut-price hotel. Aided by a favourable dollar-pound exchange rate, Laker did well out of this market for a time, both as charter operator and as a scheduled carrier on the London - Tampa route. In 1981, however, the pound deteriorated against the dollar and the sun worshippers drifted back to the parched littorals of Spain.

None of it was enough. Laker Airways entered the 1981 recession with three fatal weaknesses: over-capacity, under-capitalisation and a portfolio of loans denominated in dollars. The annual growth of passenger traffic across the Atlantic, which had been averaging $12 \%-15 \%$ during the late 1970 s, slowed to $1.5 \%$ and the world's airlines were losing money - $\$ 600 \mathrm{~m}$ on the North Atlantic routes alone. Laker Airways was not alone in this respect. What set it apart was its lack of cash reserves, which meant that its ability to repay the outstanding $£ 111.4 \mathrm{~m}$ in loans and hire purchase balances depended entirely on the generation of revenue. Viewed from this angle, the accounts for the year to March 1980 made an exciting read. Current assets were $£ 19.7 \mathrm{~m}$ of which only $£ 4.8 \mathrm{~m}$ was cash or near-cash. Current liabilities were $£ 31.5 \mathrm{~m}$. As for the ability to generate revenue, group profit, as already noted, had declined to a mere $£ 236,080$ on turnover of $£ 111.4 \mathrm{~m}$.

In a characteristic note of good cheer, Laker insisted that profits would have been at least $£ 5 \mathrm{~m}$ higher but for the grounding of the DC10s. The claim may have backfired, since it drew attention to another problematic feature of the balance-sheet. Laker's aircraft and spare engines were valued at cost - $£ 136.4 \mathrm{~m}$ - as against the $£ 111.4 \mathrm{~m}$ in long-term debt which had financed their purchase. Though Laker claimed that his atcost valuations were conservative, probably because of his successes in beating down the asking prices, the reality was that the Paris crash of 1974, followed by that of the American Airlines aircraft in 1979, had virtually wiped out the market for DC10s, new as well as used. There was therefore little prospect of paying off the loans through a fire-sale of DC10s. That left the three Airbuses. Unfortunately for Laker, the loan for these aircraft contained a clause that the interest rate subsidy would cease if any of them were sold. 
These difficulties were compounded by a deterioration of the pound against the dollar. Whereas all of Laker's $\$ 400 \mathrm{~m}$ or so in loans were denominated in dollars, about two thirds of his revenue was in pounds. When the loans were first negotiated, the average exchange rate was $\$ 2.24$. At the time of his insolvency, it had dropped to $\$ 1.80$, meaning that the burden of his loan repayments had effectively increased by about $16 \%$.

In August 1981 it was revealed that Laker was attempting to re-schedule payments on the EXIM loan with which he had purchased his last five DC10s. The CAA were quickly on the case. They concluded that Laker Airways was in urgent need of at least $£ 5 \mathrm{~m}$ in capital and alerted the Treasury, the Department of Enterprise and the Bank of England. Concerned at Laker Airways' lack of financial management, the Bank of England prompted the Midland to provide some. As it became clear that Laker would also be unable meet the payment on the Airbus loan, the Midland Bank convened a meeting in November 1981 between Laker, his newly installed financial advisors and all of the banks and manufacturers involved in both syndicates. There was little room for manoeuvre. Either the airline could be forced into insolvency at once or the repayments would have to be postponed long enough for it to benefit from the peak booking period in June and July of 1982. A deal was hammered out. Airbus Industrie would help Laker to find a buyer for the three A300s after the 1982 peak booking period, and fund the $25 \%$ first-loss guarantee. The Midland syndicate would forego the $\$ 13 \mathrm{~m}$ a year interest payments on the loan until the sale and fund the rest of the loss. McDonnell-Douglas and General Electric, who were looking at a bill for about $\$ 55 \mathrm{~m}$ for their first loss guarantee should Laker go under, agreed to a conversion of $\$ 55 \mathrm{~m}$ of the Exim loan into preference shares in return for a termination of the guarantee. As well as this reduction in Laker Airways' burden of loan repayments, the American manufacturers agreed to inject $£ 4 \mathrm{~m}$ and $£ 1 \mathrm{~m}$ of share capital respectively into Laker Airways, thus meeting the CAA's investment requirements.

The deal never had a chance. Pan-Am had suffered mounting losses throughout 1981, to the point where its major creditor, Chase Manhattan led a campaign which ousted the company's chairman in favour of one Ed Acker, a man who Laker-like had built up Air Florida on the basis of cut-price fares. Sticking with what he knew, Acker promptly slashed Pan Am's fares on the North Atlantic route by almost 60\%, prompting BA and TWA to follow suite. At these fares, all three airline were losing money even with their aircraft full, but unlike Laker, they had the reserves of capital or the state backing to stand it. Laker's customers deserted him in droves. January is traditionally a slack season, but the load factors on Laker's aircraft dropped to $40 \%$, as compared to the anticipated 55\%. The airline's overdraft edged towards its limit of $£ 9 \mathrm{~m}$ and the CAA upped its estimate of the capital requirement from $£ 5 \mathrm{~m}$ to $£ 10 \mathrm{~m}$.

The American manufacturers, meanwhile were waking up to the fact that their investment in Laker Airways would have made them the majority owners of an airline which was in competition with their other customers. General Electric withdrew from the deal altogether, whilst McDonnell-Douglas, anxious to avoid the return of its DC10s given the state of the market for them, left the money on the table, but as a loan rather than equity. This, of course, was no good. The Midland Bank insisted that Laker would have to find his $£ 5 \mathrm{~m}$ in equity from some other source and that, apart from a number of frantic phone calls, was that.

On the $5^{\text {th }}$ February, 1982 Laker Airways was declared insolvent and all of its aircraft were immediately grounded. One flight on its way to Tenerife with 300 passengers on 
board was turned back as it passed over the Bay of Biscay. In all, about 6,000 holiday makers were stranded abroad by the collapse, and other airlines were able to gain valuable publicity by organising rescue schemes. A 'Save Freddie Laker' fund was set up with the help of Lloyd's bank, eventually attracting about $£ 3.5 \mathrm{~m}$. Donations included $£ 1,000$ left at Laker's offices by a 76-year-old woman (Hellary, 2001).

\section{Conclusions, Various}

Banks' account of the collapse was published in 1982, the year in which it occurred. In that year, Laker was 60. He lost his horse-stud, his 1000 acre farm, his Tudor home, his luxury yacht, and his cars, a Rolls-Royce and a Jaguar. He was stripped of membership of Lloyd's and lost the free travel pass traditionally given to the presidents of the world's airlines. Banks offered the opinion that he was unlikely to bounce back (1982, p. 153-4).

Later in 1982, the liquidators of Laker Airways sued twelve airlines for conspiracy to bring the company down. Under the Freedom of Information Act, Laker's American lawyer, Bob Beckman obtained the minutes of the IATA meetings of 1977 at which the airlines had negotiated their cut fare deals in response to Skytrain. The collusion was obvious, and in 1985 the case was settled. According to one report the amount was $\$ 300 \mathrm{~m}$, enough to pay off creditors, staff and the pension fund (Huettel, 2001). In a separate deal, British Airways offered Laker a personal settlement of £8m to drop his case. At the last minute, he trousered the cash leaving his ex-employees to fight on alone (Hellary, 2001)

Also in 1982, shortly after the Skytrain collapse, an American lawyer called Randolf Fields recruited two of Laker's key executives and applied to the CAB to take over his Atlantic licence. Short of capital, Fields approached one Richard Branson, who immediately sought advice from Laker. Eventually Branson succeeded in dealing Fields out of his airline (ambiguity intended) and it became part of the Virgin empire. Later, when Virgin Atlantic became locked in a dispute with BA over alleged 'dirty tricks' to poach passengers, it was Laker who advised Branson to 'sue the bastards.' Branson duly did so: for libel in the UK, settling for $£ 610,000$, and, borrowing Laker's lawyer, Bob Beckman, in an anti-trust suit in the USA which failed (Bower, 2001, pp. 156, 335).

Baroness Margaret Thatcher, the former UK Prime Minister, who adopted Laker as her symbol of the enterprise culture whilst the going was good, once described him, with a characteristic lapse into innuendo ${ }^{1}$, as 'My knight in a shining fuselage.' The Baroness, sad to say, has tarnished in her knight's memory. This is Laker speaking in an interview of 2001, 'Margaret Thatcher . . . used to say, "Competition works. Look at Freddie Laker." That was her byline. But when the chips were down, whether she was going to allow competition or not, she went with British Airways and dropped me like a hot potato.' (Huettel, 2001)

79 years old at the time of writing, Laker still runs an airline. Laker Airways (Bahamas) Ltd. began operating in 1992 and still flies tourists to the Bahamas in two 175-seat Boeing 727s (Huettel, 2001). He holds honorary doctorates of science at the University of Manchester, the City University and the Cranfield Institute of

\footnotetext{
${ }^{1}$ Speaking of her faithful factotum, William Whitelaw, she famously failed to resist the bon mot, 'Everybody needs a Willie'.
} 
Technology, plus an honorary doctorate of law from Manchester (Lakerbio). The spirit of Skytrain lives on in the annual 'Freddie' awards for the airline with the best frequent flyer deal, sponsored by InsideFlyer and other in-flight magazines (Webflyer, 2001).

As the years go by, fewer and fewer Carvairs clamber into the skies to commemorate Aviation Traders, whilst all that survives of the Accountant is the nacelle design of the BAe ATP - or so Sir Freddie Laker will believe to his dying day.

\section{Sources}

Banks, Howard (1982) The Rise and Fall of Freddie Laker. London. Faber \& Faber.

Bower, Tom (2001) Branson. London. Fourth Estate.

Carvair = http://www.geocities.com/anjapaul/carvair.htm Accessed 5/9/01.

Eglin, Roger and Ritchie, Berry (1980) Fly Me, I’m Freddie. London. Weidenfeld and Nicholson.

Heal, Lionel Charles (1954) Patent No. GB702981 Improvements relating to the construction of hollow bodies of streamline form.

Heal, Lionel Charles (1956) Patent No. GB756392 Improvements relating to the production of skin-stressed surfaces.

Hellary 2001 = http://hound.hypermart.net/history.htm Accessed 13/07/01. Page by Philip C.P.C. Hellary, son of Laker Airway’s one-time chief pilot, Capt. Alan Hellary.

Huettel, Steve (2001) Still a feisty flyer. St. Petersburg Times, June $16^{\text {th }}$

(http://www.sptimes.com/Business.shtml Accessed 5/9/01)

Jane’s All the World’s Aircraft. 1956 London : Jane's Publishing

Jane’s All the World's Aircraft. 1957 London : Jane's Publishing

Laker Airways (International) Limited. Annual Report and Accounts to March $31^{\text {st }}$ 1980.

Lakerbio = http://www.webflyer.com/@livefly/fred11th/lakerbio.htm Accessed 22/Aug/01

Merton-Jones, Tony (1985) Laker and the Forgotten Airliner: the Avro Tudor in Air Charter Service. Propliner, No. 23, Summer. pp. 26-32.

NS archive, Laker 1 = http://www.gwu.edu/ nsarchiv/coldwar/interviews/episode4/laker1.html Accessed 5/09/01

NS Archive, Laker 3 = http://www.gwu.edu/ nsarchiv/coldwar/interviews/episode4/laker3.html Accessed 5/9/01

Webflyer = http://www.webflyer.com/@livefly/fred11th/pr-1.htm Accessed 13/07/01 